\title{
Alternative Measures of Australia's External Indebtedness
}

\section{Scott Austin}

$\mathrm{E}$ conomics is fundamentally concerned with how people maximise their well being with limited resources. Economists are, therefore, interested in measuring these resource, or wealth, constraints. Some statistics are more useful for this purpose than others. GDP per capita is a commonly used measure of real living standards. With some qualifications, an increase in GDP per capita is generally regarded as a welfare improvement. It is also relatively uncontroversial that a rise in the unemployment rate represents a decline in aggregate welfare. By examining how these statistics impact on people's wealth constraints we are generally able to infer how welfare is affected.

As is well known, the current account deficit, which has featured prominently in Australian economic policymaking, provides no meaningful information about welfare changes. Australia's current account is a reflection of the underlying savings and investment decisions by individuals, companies and governments. These savings and investment decisions are determined by preferences, technology and wealth constraints.

Less well known is that the current account deficit may not be a good measure of changes in Australia's net external liabilities. In popular opinion, Australia's current account deficit represents the extent to which we are 'selling off the farm' and imposing a burden on future generations. However, the current account deficit represents only part of the change in net external liabilities over a given period. In particular, focussing only on the current account ignores any valuation effects on the existing stock of net external liabilities.

This paper considers two interrelated issues. First, it examines the extent to which the conventionally measured, current account, represents changes in net external indebtedness. This is largely a question about how to properly measure changes in net external liabilities. Second, it examines the relationship between a properly constructed measure of changes in net external liabilities and the welfare of the average Australian. This is a question about how data relating to net external liabilities should be interpreted.

This paper contributes to informed debate by providing an appropriate measure of changes in net external liabilities for Australia. As will become evident, the calculation underlying our measure involves a number of judgements on which there may be disagreement. One of the objectives of this paper is to expose these judgements for debate. Because it is the perceived link between the

Scott Austin is Lecturer in Economics in the faculty of Economics at The Australian National University. 
conventional current account and net external liabilities that has motivated much of the recent policy interest in the current account, a secondary objective of the paper is discuss the linkage (or lack thereof) between our current account measure (hereafter denoted the adjusted current account, or ACA) and changes in welfare.

\section{Importance of Correct Measurement of the Current Account}

In the popular conception, a current account deficit of, say, $\$ 100 \mathrm{~m}$ is conceived of as an increase in net Australian liabilities of the same amount. This conception is flawed because it ignores:

- the effect of changes in the value of existing net debt because of exchange rate changes and interest rate changes;

- the effect of changes in the market value of assets owned by Australians offshore;

- changes in the present value of our foreign aid commitments; and

- changes in the present value of assets expected to be brought by migrants coming to Australia.

An individual's wealth is the accumulation of all past savings together with the present value of all anticipated future income. These represent the present value of all resources available to that individual over his or her lifetime. Taken together, net foreign assets at market value and the discounted value of future transfers represent the expected present value of all net resources currently available to a country from the rest of the world. An increase in the ACA will be shown to imply an increase in net external wealth for some domestic resident.

A conceptually correct measure of a country's net external wealth would therefore consist of two components. First, the market value of net external liabilities and, second, the present value of all expected net resource transfers from abroad. The second item is included because of the ability of countries to borrow against these transfers on international capital markets.

A current account deficit must be financed by foreign investment. Another way of saying this is that in a floating exchange rate regime, a current account deficit must be identically equal to the capital account surplus. The capital account measures all the transactions that add to the stock of foreign investment in Australia (FIA) or Australian investment abroad (AIA). A capital account surplus implies that purchases of Australian assets by foreigners exceeds purchases by Australians of offshore assets. These transactions are basically classified according to whether they are debt or equity investment ${ }^{1}$. The ABS also distinguishes between portfolio and direct investment.

Since the capital account focuses on transactions, it ignores valuation effects on the existing stock of net foreign liabilities. These valuation effects come about because of changes in financial markets. These include changes in interest rates,

1 There is a third classification 'other' which refers to trade credits and debits. 
share prices, or movements in the exchange rate since net foreign liabilities are converted into Australian dollar equivalents. Naturally, if the asset is denominated in Australian dollars, exchange rate movements are irrelevant for valuation in Australian dollars.

\section{Calculating net foreign assets at market value}

Exchange rate movements affect the Australian dollar value of debt denominated in foreign currency and equity investments by Australians in offshore markets. As at June 2000, 42 per cent of Australia's net foreign debt was denominated in local currency (down from almost 60 per cent three years previously). The Australian Bureau of Statistics converts external assets and liabilities into Australian dollar equivalents when compiling the international investment position, so exchange rate valuation effects will already be incorporated in official estimates of net external liabilities.

The treatment of other valuation effects is more problematic in trying to create a long time series. There are two major issues. First, prior to 1980, equity investments were not measured at current market value ${ }^{2}$. Second, the most important component of FIA, bearer debt securities (such as bonds), are also not marked to current market value. There is also an argument for valuing some debt instruments for which there is not a large secondary market (eg. term loans from banks) at book value. The major problems here are to revalue corporate equities at market value prior to 1980, and to change the value of bonds from face to market value to take into account (often volatile) movements in bond yields.

From 1979/80 official data on Australia's net external liabilities include changes in the value of foreigners' ownership of Australian equities arising from domestic share price movements. But if we are interested in changes in Australia's external net wealth (and any welfare changes which can be inferred from them), these valuation effects are, in themselves irrelevant, and are omitted from the ACA. If a foreigner owns a share in BHP, for example, and its value increases because productivity in the company has improved, this has no effect on the net worth of any domestic resident (although the productivity improvement obviously increases the wealth of domestic shareholders in BHP). The argument is not symmetrical, however. An increase in the market value of Australian equity holdings abroad is a welfare improvement for some domestic residents, since it implies an increased flow of resources from abroad to those residents.

Revaluation of offshore equity investments is achieved by calculating a composite share price index using data on AIA investment in portfolio corporate equities and direct corporate equities by country of destination. These country shares are used as weights and applied to movements in the relevant international

2 The ABS does this using sharemarket prices or directors' valuations (in the case of direct equity investments). 
share price index. The share price indices used are typically 'all industrial' prices $^{3}$.

The revaluation of net foreign debt to market requires some simplifying assumptions. Consider first offshore government debt. The Australian government budget papers provide data on Commonwealth government bonds domiciled offshore (typically denominated in foreign currencies) and those domiciled in Australia. To calculate the revaluation factor for interest rate changes, the interest rate on official sector debt domiciled offshore is substituted into a standard bond pricing formula. The weighted average term to maturity of non-official holdings of marketable government securities is taken from RBA data $^{4}$. In the absence of information on the split between fixed and floating rate debt, a six-monthly coupon payment of 6.75 per cent is assumed.

Data on private sector offshore debt are harder to come by. By necessity, therefore, the debt revaluation factor calculated for the official sector is also applied to non-official borrowings. Prior to the 1980s, non-official portfolio debt was at negligible levels so the issue of revaluing non-official debt is a relatively minor one. However, during the 1980s, private sector offshore borrowing was the fastest growing component of Australia's external liabilities and revaluation of these liabilities takes on increasing importance. By applying an official sector revaluation to private debt we are assuming that private sector debt structure (yield, maturity structure and currency denomination) is the same as that of the public sector. This is obviously not the case. However, in calculating the intertemporal measure of the current account we use the change in net foreign assets at market value. The application of official bond prices to non-official debt will be a reasonable approximation in calculating the ACA if: movements in private yields have mirrored those of government bond yields (that is, if any private risk premium has been relatively constant); the currency composition and maturity structure of private debt is similar to that of public debt; and, the public/private split of net external debt has remained relatively stable. These assumptions are highly debatable (although more palatable than the assumption that the yields on private and public debt were the same). To the extent that private sector risk premia have been growing over time (and the gap between private and government bond yields has been rising) this will tend to overstate the rise in the market value of non-official external debt.

Other factors complicate the revaluation of private debt, since some of it is variable-rate. The extent to which this will bias the valuation depends on how the split between fixed and variable interest debt has evolved over time. Other potential complications flow from the growth of new offshore debt markets and use of derivatives. For example, from mid-1985 Euro-debt markets assumed an increasing importance as a source of private sector finance. Since these securities

3 Share price indices were used for the countries which received the bulk of AIA equity investment: the United States, Japan, West Germany, Japan, New Zealand, Hong Kong, South Korea, Taiwan and Papua New Guinea.

4 Foster, R. A. and S.E.Stewart (1991). Table 2.21, Reserve Bank of Australia Bulletin Table E8. 
are not denominated in Australian dollars, it is unlikely that their yields move with those on Australian dollar denominated securities. The difficulty in obtaining relevant Euro-rates precludes more detailed analysis.

Figure 1: Net Foreign Liabilities

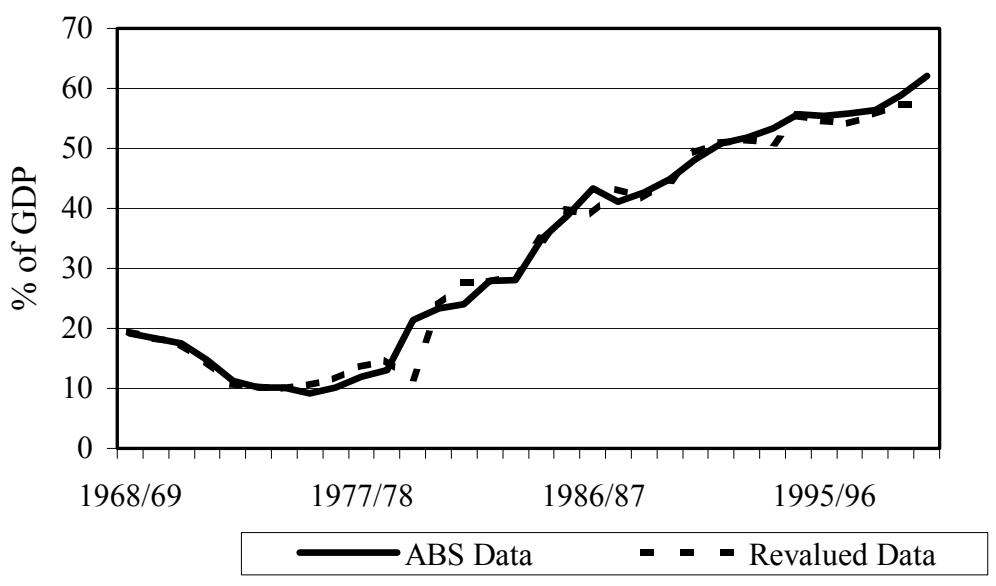

Figure 1 shows the revalued levels of Australia's net external liabilities, together with the official Australian Bureau of Statistics (ABS) data. The revalued series differs in two basic ways from the ABS series. First, it includes the revaluation of debt securities to market as discussed above. This debt revaluation tends to increase the value of Australia's net external liabilities. Second, it excludes movements in the value of foreigners' holdings of Australian equities caused by movements in the local share market. Removing these equity valuation effects tends to reduce the value of Australia's net external liabilities. For example, in 1999/00, equity valuations added the equivalent of 5 per cent of GDP to foreign investment in Australia. As Figure 1 shows, these effects have been roughly offsetting over time with the two series moving very closely together.

\section{Calculating net expected transfers}

As discussed earlier, the presence of transfers in the current account makes it an unreliable indicator of changes in net external liabilities. Consider the following example. Imagine a country has a commitment to provide financial aid to another country. It could choose to provide the aid in the form of on-going payments that would be reflected each year as a debit on its current account. Alternatively, it could choose to provide a once-only payment, equivalent in present value terms to its commitment to the other country. In the first case, there would be a relatively small, on-going impact on transfer payments (and therefore on the conventional current account). In the second case, the conventional current account balance would record a large fall initially, which would be subsequently unwound in the following year. In both cases, the implications for net resource transfers between 
the two countries are identical. The conventional current account, however, gives a widely divergent view of the two policies.

Figure 2: Unrequited Transfers

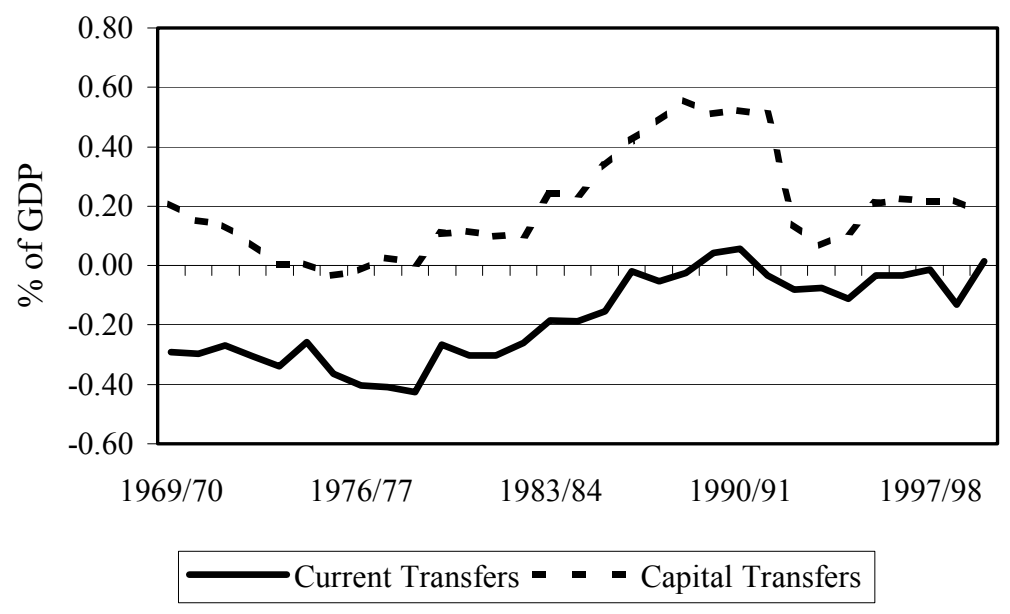

'Unrequited' transfers (plotted in Figure 2) are one-way resource flows that are unrelated to an underlying transaction in goods, services or financial assets. In 1997, the Australian Bureau of Statistics abandoned the use of the term 'unrequited transfers' and opted for a classification of transfers according to whether they were of a capital or current nature. Capital transfers basically consist of the movement of financial assets by immigrants from their country of origin to the new country of residency. These transfers have always been in surplus for Australia. Current transfers consist of items such as foreign $\operatorname{aid}^{5}$ or contributions to international organisations. Capital transfers are now included by the ABS in the capital account; current transfers are measured as part of the current account. This relabelling of transfers (which, by removing the surplus on migrant capital inflows, added over $\$ 1$ billion to the conventional current account deficit in 1996/97), highlights the potential dangers of relying on the conventional current account as an indicator of changes in net external liabilities.

In order to calculate the ACA, we can calculate expected values for these one-way transfers into an indefinite future and then discount them back to the present. In doing this, we are treating the capitalised value of expected inflows as an asset. The expectations mechanism that we assume people follow is obviously important here, and others may not wish to extrapolate the recent past into the future as we propose to do. But recall that expected income is relevant because it

5 Foreign aid transfers that are deemed to be of a capital nature are included as capital transfer debits. 
determines future spending (and hence current savings). Here we incorporate adaptive expectations by assuming that people extrapolate the average value of net transfers for the most recent five year period into the indefinite future, and this seems at least as reasonable as giving future transfers a zero value. It is this income stream which is discounted to give the values presented in Figure 3. As noted above, the major components of unrequited transfers are immigrant remittances and foreign aid. In addition to being influenced by government policy, net migration to Australia tends to be highly procyclical. Here, in an attempt to moderate the effects of the economic cycle, we assume that individuals expect that the average level of immigration-related transfers over the previous five years will continue into the indefinite future.

Figure 3: Present Value of Net Unrequited Transfers

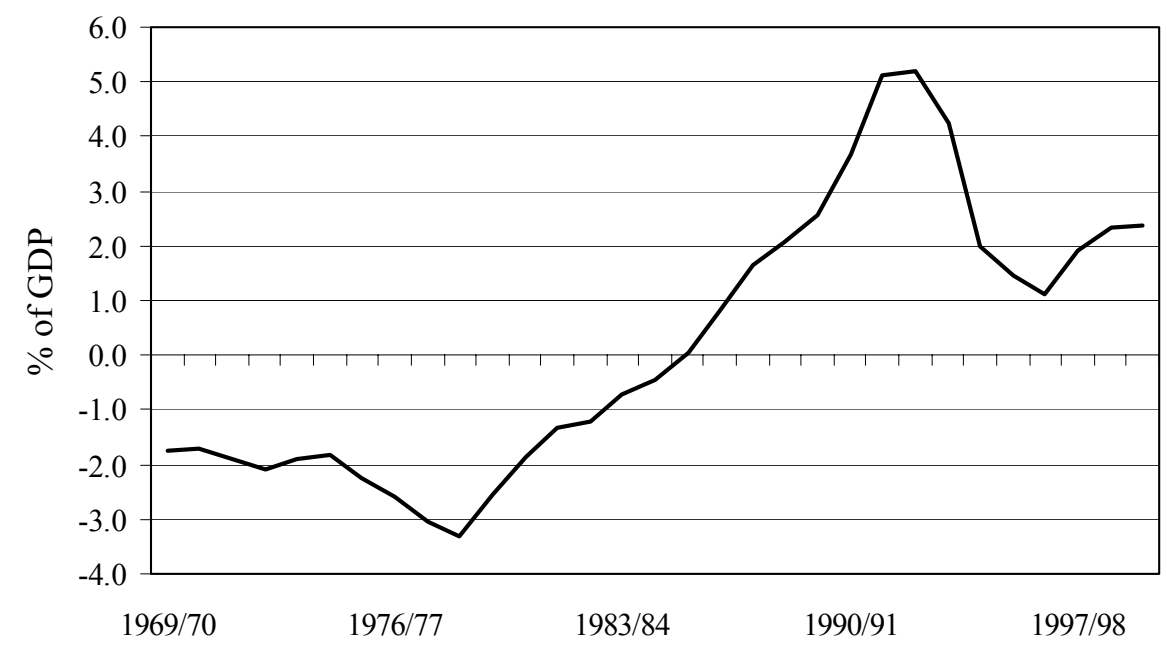

As an alternative to simple adaptive expectations mechanism discussed above, the ACA was also calculated using the net immigration projections published by the Australian Bureau of Statistics (ABS 1998) together with recent data on average migrant capital inflow. There is only a negligible difference in the calculated ACA using these data.

In calculating estimates of wealth, the choice of a discount rate is often controversial. Typically a riskless rate is chosen. However, as Haveman (1994) notes, there may be an argument for discounting transfer credits at a higher rate than transfer debits. A risk averse individual is one who would pay to avoid volatility in income receipts. For such an individual, the certainty-equivalent present value of a stream of risky income (the amount he or she would accept as an upfront payment in lieu of the income stream) is less than that of an income stream that has no volatility. In the case of transfers from Australia, the argument 
is reversed, since foreign residents bear the risk. Here the discount rate is assumed to be a 5 year average of the nominal yield on Commonwealth 10 year bonds. Within reasonable bounds, changes in the discount rate do not have a large impact on our calculations.

Figure 3 summarises the results of assuming that, at any point in time, people expect the average value of net transfers over the most recent five-year period to continue perpetually. As discussed above, this stream is discounted by the nominal government bond yield to give the values presented in Figure 3. As Figure 3 shows, these discounted values move from a negative value (ie., an expectation that there will be ongoing net transfers to foreigners) to a positive value in the mid-1980s. As Figure 2 shows, this is a combination of two factors. The first effect is the dramatic improvement in the surplus on capital transfers associated with the focussing of the immigration program on business migration (notwithstanding the fall in net migrant remittances to Australia following the recession of the early 1990s). Secondly, since the mid-1980s, there has been a steady decline in the deficit on current transfers to a position of approximate balance.

\section{Trends in the Adjusted Current Account}

Figures 1 and 3 present our measure of two components of net external liabilities. The aggregate of these components represents a broadly defined measure of net foreign assets:

$$
A_{t}=N F A_{t}+\sum_{s=1}^{\infty} \frac{E\left(I_{t+s}\right)}{\left(1+i_{E}\right)^{s}}
$$

where $N F A_{t}$ is the market value of net foreign assets at the end of period $t, E\left(I_{t}\right)$ are expected nominal income transfers during period $t$, and $i_{E}$ is the expected nominal interest rate. The ACA is then the change in the stock defined in equation (1) and Figure 4 shows both the conventionally measured and the intertemporal current account (ACA), together with the component series of the latter.

The first point to note is that, although derived from different data sources, the two measures of the current account are positively correlated (with a correlation coefficient of 0.46). The second difference is that, with minor exceptions, the deficit on the ACA has been smaller than the conventionally measured current account deficit. In the 1990s, by traditional measures the current account deficit has fluctuated between 4 and 6 per cent of GDP. On the other hand the ACA has tended to be a deficit of around 2 per cent of GDP. Both measures of the current account deficit deteriorated somewhat from the mid1970s, but appear to have levelled out in the mid-1980s. As the bottom panel of Figure 4 shows, new capital transactions (roughly corresponding to the conventional current account deficit) have consistently increased the deficit on the ACA. 
Figure 4: Alternative Measures of the Current Account
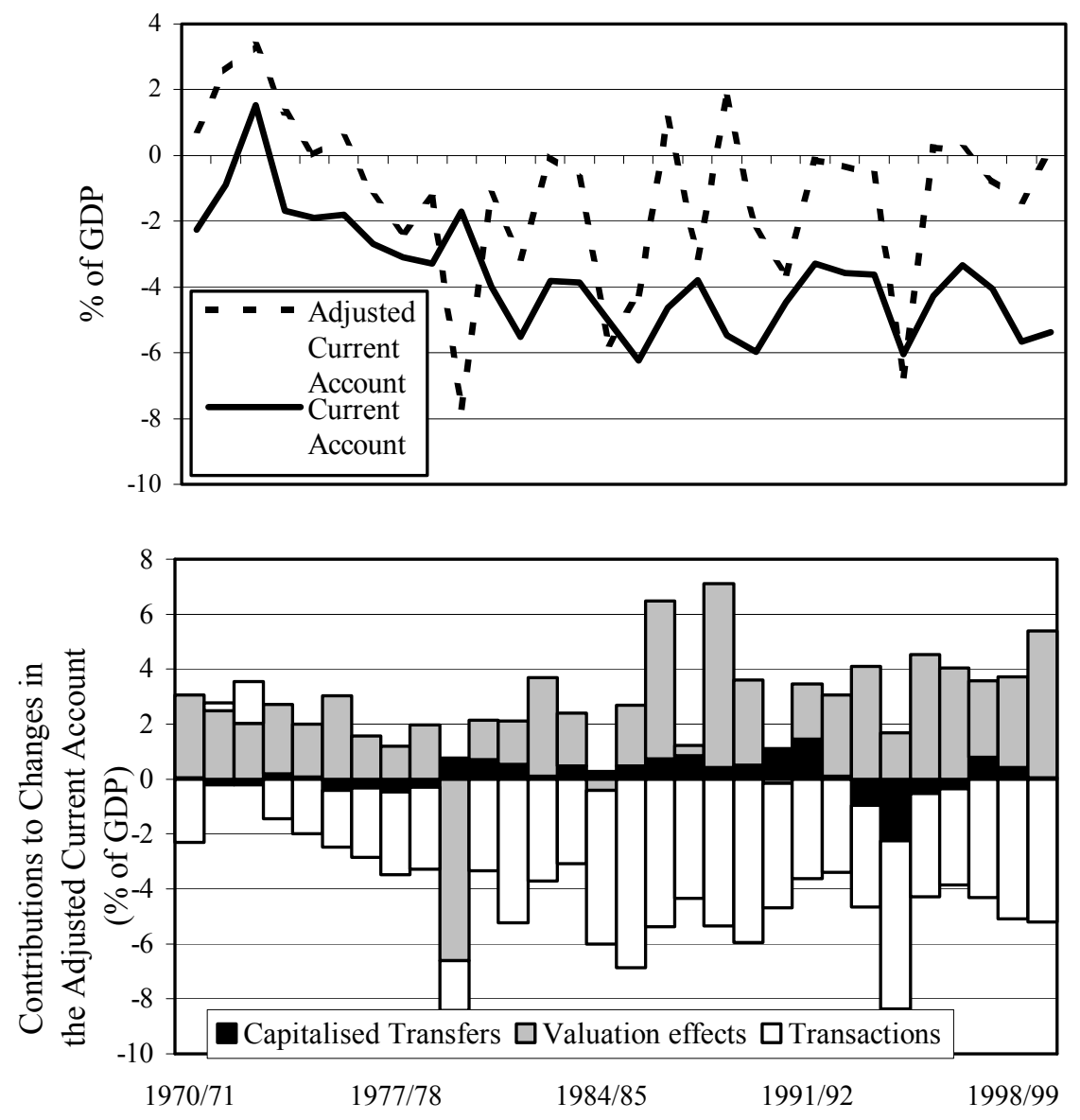

With the exception of the early 1990s, capitalised net expected transfers have tended to reduce the ACA deficit. As Figure 3 shows, the discounted value of expected net unrequited transfers rose from minus 1.3 per cent of GDP in 1982/83 to over plus 5 per cent of GDP a decade later. This largely reflects the focus on the business migration program from the mid-1980s that considerably boosted the surplus from net migrant transfers. In 1998/99, net migration totalled 117,335. On average, the contribution of each immigrant was $\$ 13,719$. This compares with net immigration of 128,117 in 1981/82 and an average net contribution of $\$ 5,167$ (in 1998/99 dollars).

Valuation effects (shown in the bottom panel of Figure 4) have also tended to reduce the deficit on the ACA. The magnitude of the positive contribution from valuation effects has also increased markedly since the floating of the dollar in late 1983. As noted above, these valuation effects are caused by changes in the Australian dollar exchange rate and by movements in domestic and international 
share prices and interest rates. There was a positive contribution from foreigners paying an inflation tax on holdings of Australian issued fixed interest securities. During the 1970s and 1980s, Australia ran consistently higher inflation rates than the countries that were the major suppliers of capital to Australia (the US, Japan and the United Kingdom). If purchasing power parity held it might be expected that exchange rates would move to somewhat offset these differentials. However, as noted above, not all external debt is denominated in foreign currency (over the 1980s and 1990s approximately 40 per cent was denominated in local currency). In this case, exchange rates will have no direct impact on whether or not foreigners pay the inflation tax.

It is not surprising that these valuation effects would tend to boost the ACA compared to the conventional current account. Recall that the ACA removes valuation effects from foreigners' holdings of Australian equities. In order to quantify the possible magnitude of this effect, the ACA was also calculated with valuation effects on FIA equity investments (as is the official practice). These equity valuation effects could either increase or decrease the deficit on the ACA. In recent years, this has led to a fall in the ACA deficit. Over the 1990s, the ACA with FIA equity revaluation averaged 2.0 per cent of GDP (compared to 1.4 per cent of GDP for the ACA as shown in Figure 4). Over the 1980s, removal of equity revaluation implied, on average, virtually no difference in the ACA deficit. Following the removal of capital controls in Australia, the private sector has been responsible for the overwhelming majority of capital inflow. Following deregulation, we would therefore expect capital from Australia to seek out the highest rate of return. For example, as Robertson (1990) notes, the accumulation of foreign debt over the 1980s was not only used to finance current account deficits but also to accumulate offshore equity investments. Reversing earlier trends, there was a net equity outflow by the mid-1980s. That is, Australians were accumulating offshore equity claims at a faster rate than foreigners were accumulating equity claims in Australia.

\section{Interpreting Movements in the Intertemporal Current Account}

Over the past fifty years, the current account has occupied a pre-eminent role in Australian macroeconomic policy making. In the period prior to the floating of the exchange rate in December 1983, the balance of payments was viewed with interest because it represented changes in the Reserve Bank's foreign exchange reserves. Policy makers were concerned about the current account because of its link to the sustainability of the exchange rate. Discussion about 'external balance' was primarily motivated by the concern to maintain a stable level of international reserves (Pitchford, 1995:6). More recently, concerns have been raised about the sustainability of Australia's current account deficit in the face of a rapid expansion in net external liabilities. The monetary policy tightening which lead to the 1990/91 recession was prompted in large part by these concerns.

In one sense, concern over developments in the current account might seem natural. Over the past two decades, net external liabilities have risen dramatically 
from 21 per cent of GDP to 62 per cent of GDP. Within this total, net external debt has risen from 8.2 per cent of GDP to 42.5 per cent of GDP. However, from the mid-1980s, some economists, including John Pitchford (Pitchford 1990 and 1995), questioned the view that Australia's current account necessarily represented a policy dilemma. They noted that the overwhelming majority of net foreign liabilities were issued against the private sector. Net government foreign debt was a relatively small component of the total ${ }^{6}$. A large current account deficit might be a reflection of structural problems elsewhere in the economy (for example, the tax system). But, to target the current account as a policy objective was considered analogous to focussing on the symptoms of a disease rather than the cause.

The previous section of the paper has established that the conventional measure of the current account, which was the empirical basis for much of the Australian policy debate, may give a misleading picture of the change in Australia's net external liabilities. We now consider whether the welfare implications of changes in the current account are affected by the use of the ACA rather than the conventional current account deficit. According to Fisher ${ }^{7}$ (1995),

[i]n the open economy, what matters is a measure of the present value of net transfers from abroad...the annual change in the expected present value of net transfers from abroad, is an appropriate measure of the external deficit. If the [ACA] worsens, then some domestic resident will suffer lower utility. This simple fact is not true of the conventional current account.

Fisher (1998) and Fisher and Woo (1997) estimate this measure for Japan and for South Korea, respectively. However, when linking changes in external liabilities to national welfare changes, the position may not be as unambiguous as Fisher suggests in the above quote. Welfare changes may occur, after all, from domestically sourced changes in wealth (such as a productivity shock or the discovery of a new natural resource). As with the conventionally measured current account, linking a change in Fisher's measure of the current account to welfare will normally involve first identifying the factors which caused the change. Nonetheless, Fisher's measure represents a significant step in the right direction.

According to Fisher (1997) a lower deficit (correctly measured) unambiguously represents a welfare improvement for some domestic resident, either now or in the future. This is because such a deficit reduction 'shows that

6 In 1995/96, official gross external debt (incorporating the borrowings of all levels of government) was about a third of the total.

The calculations made by Fisher were an important motivation for this paper. His calculation is based on an overlapping-generations model of the economy. He therefore called his adjusted current account measure the 'Aggregate Generational Current Account (AGCA)'. Except for some differences in the treatment of valuation effects, Fisher's AGCA is essentially the same as the ACA presented here. 
some domestic resident has higher wealth abroad'. Hence Fisher links domestic welfare to changes in net external assets. However, this assumes that all welfare changes are externally sourced. A nation also derives wealth from domestically owned resources. The extent to which we utilise these resources will depend on a number of factors, primarily the cost of investment and technology. With this in mind, we can only make a qualified link between welfare and the ACA. For instance, the following three examples of wealth inducing shocks are potentially very important for a small open economy like Australia. In each case, relying on the ACA as an indicator of welfare change may give the wrong answer.

A productivity improvement is unambiguously a welfare improvement for a country. It increases domestic output of goods and services from the existing capital stock. This improvement in capital productivity will induce additional investment. The rise in permanent income induces an increase in consumption. It may be the case, that these increases in investment and consumption outweigh the permanent increase in income and lead to an increase in external indebtedness. (Forsyth 1990) makes a similar point for the conventional current account deficit.

A real interest rate fall is also an unambiguous welfare improvement for a small debtor nation. However, again, the implications for the ACA are unclear. The fall in interest rates induces an increase in current consumption and investment, thereby raising the current account deficit immediately. On the other hand, it also increases the present value of income transfers from abroad and reduces interest payments on existing debt. The overall impact on the ACA is ambiguous.

The removal of controls on capital flows in Australia in the late 1970s and early 1980s was followed by a dramatic surge in private offshore borrowing is indicative of a welfare improvement since the capital controls appeared to have restricted domestic below its optimal level. Yet, it is not clear that the ACA would show an increase following their removal since, initially, the removal of these controls would imply an increase in external liabilities. Indeed, from Figure (4), it appears that the deficit on the ACA increased along with the deficit on the conventionally measured current account in the period following the liberalisation of capital controls and the floating of the Australian dollar in December 1983.

Another potential point of ambiguity about how the ACA links to welfare changes is whether a decrease in the capitalised value of net unrequited transfers to Australia necessarily represents a welfare reduction. As noted previously, unrequited transfer debits include foreign aid payments. Here we are treating these payments, along with all other net transfer debits as a resource transfer away from Australia (which is exactly what they are). However, along with official aid programs, these transfers include donations from individual Australians who, presumably, derive utility from making them. In the same way that a permanent rise in consumption (for example, caused by a fall in interest rates) leads to a rise in welfare but may lead to a fall in the ACA, here an increase in private foreign aid donations would be welfare improving (since they are voluntary) but lead to a fall in the ACA. There is therefore a case for omitting these payments when 
making welfare judgments. For Australia, however, these aid payments have made a negligible contribution to the ACA.

\section{Conclusions}

In the popular imagination, the current account deficit measures the extent to which Australia is 'selling off the farm'. However, since it ignores valuation effects on the stock of net external liabilities and expected future transfers, the conventionally measured current account deficit is flawed as an indication of the change in a country's net worth relative to the rest of the world. The above analysis suggests that the conventional current deficit might overstate the extent of future resource transfers by as much as 7 per cent of GDP. Measuring the current account deficit in a conceptually correct way, therefore, is quantitatively significant.

This is not to say that the conventional current account is irrelevant. Capital markets, concerned about the sustainability of Australia's net international investment position, focus on it as a readily available statistic that measures the accumulation of new net foreign liabilities. But it should be interpreted with caution. As we noted previously, the ACA has a heavy informational requirement. In both constructing net foreign liabilities at market value and forming estimates of expected future resource transfers, we have had to make some heroic assumptions. In contrast, the conventionally defined current account deficit is a reasonably well-measured statistic.

We have also argued that, contrary to the assertion in Fisher (1995), the correct measurement of net external liabilities does not, of itself, provide a means by which changes in the ACA can be associated with changes in welfare. Just as with the conventional current account, we need to know the source of the change in the ACA.

\section{References}

ABS (1998), Population Projections: 1997 to 2051, Australian Bureau of Statistics (Cat. No. 3222.0).

Fisher, E. (1995), 'A New Way of Thinking About the Current Account', International Economic Review 36:555-68.

Fisher, E. (1998), 'A Measure of the Current Account Related to the Well-Being of Japan: Generational Accounts in the Open Economy', pp 315-34 in R. Baldwin, R. Lipsey and J. Richardson Geography and Ownership as Bases for Economic Accounting,. University of Chicago Press, Chicago.

Fisher, E. and Y. Woo (1997), 'Meaningful Measures of the Current Account', Review of International Economics 5(4):452-466.

Forsyth, P. (1990), 'Why Microeconomic Reform Won't Reduce Foreign Debt', Policy (Winter):13-16. 
Foster, R. and S. Stewart (1991), Australian Economic Statistics: 1949-50 to 1989-90, Occasional Paper No.8, Reserve Bank of Australia, Sydney.

Haveman, R. (1994), 'Should Generational Accounts Replace Public Budgets and Deficits?' Journal of Economic Perspectives 8(1):95-111.

Pitchford, J. (1990), Australia's Foreign Debt: Myths and Realities, Allen and Unwin, Sydney.

Pitchford, J. (1995), The Current Account and Foreign Debt, Routledge, New York.

Robertson, R. (1990), 'Australian Equity Investment Abroad,' Reserve Bank of Australia Bulletin (March).

The author would like to thank Graeme Wells, Ross McLeod and two anonymous referees for comments on an earlier version of the paper. 